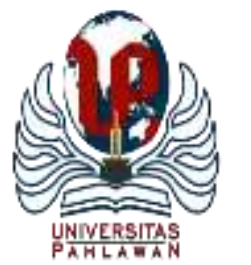

Edukatif : Jurnal Ilmu Pendidikan Volume 4 Nomor 1 Tahun 2022 Halm 201 - 210

EDUKATIF: JURNAL ILMU PENDIDIKAN

Research \& Learning in Education

https://edukatif.org/index.php/edukatif/index

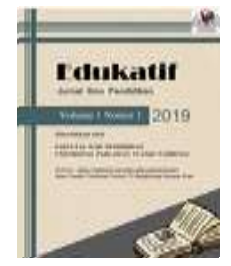

\title{
Penggunaan Media Quiziz Sebagai Sarana Pengembangan Berpikir Kritis Siswa
}

\author{
Jira Rastal Arif ${ }^{1 凶}$, Aiman Faiz $^{2}$, Lidiya Septiani $^{3}$
}

Universitas Muhammadiyah Cirebon, Indonesia ${ }^{1,2,3}$

E-mail : jira@umc.ac.id ${ }^{1}, \underline{\text { aimanfaiz@umc.ac.id }}^{2}, \underline{\text { lidiyaseptiyani3@ gmail.com }}^{3}$

\begin{abstract}
Abstrak
Keberadaan teknologi pada saat pembelajaran harus dianggap terbiasa, bahkan dimasa yang akan datang komputer dianggap sama keberadaannya dengan media alat tulis ataupun media yang tidak tergolong dalam teknologi di setiap ruangan kelas. Tujuan penelitian ini adalah untuk mengeksplor pemikiran kritis siswa melalui media quizizz. Pendekatan penelitian ini adalah kualitatif dengan metode deskriptif analitik. Hasil penelitian mengungkapkan bahwa penggunaan media quizizz dan teka-teki silang berbasis website dapat membentuk daya berpikir kritis saat menjawab pertanyaan kuis. Hal ini dibuktikan dengan pengamatan atau observasi via zoom saat pengerjaan sedang dimulai. Tidak hanya itu observasi juga melihat hasil akhir pengerjaan dalam siswa menjawab kuis-kuis quizizz dan teka-teki silang. Penggunaan media website permainan edukasi dalam pembelajaran online dengan media quizizz dan teka-teki silang menunjukkan hasil bahwa mampu membentuk berpikir kritis siswa dalam pembelajaran online. Media mampu merangsang proses kecerdasan dan kemampuan berpikir siswa dengan berbagai konten keilmuan didalamnya
\end{abstract}

Kata Kunci: Berpikir kritis, penggunaan media, quizizz

\begin{abstract}
The existence of technology at the time of learning must be considered accustomed, even in the future computers are considered to be the same as stationery media or media that are not included in technology in every classroom. The purpose of this study was to explore students' critical thinking through quizizz media. This research approach is qualitative with an analytical descriptive method. The results of the study revealed that the use of quizizz media and website-based crossword puzzles can form critical thinking power when answering quiz questions. This is evidenced by observations or observations via zoom when the work is being started. Not only that, but observations also saw the final results of the work in which students answered quizes and crosswords. The use of educational game website media in online learning with quizizz media and crossword puzzles shows the results that can form students' critical thinking in online learning. Media can stimulate the process of intelligence and students' thinking skills with various scientific content in it.
\end{abstract}

Keywords: Critical thinking, media use, quizizz.

Copyright (c) 2022 Jira Rastal Arif, Aiman Faiz, Lidiya Septiani

$\triangle$ Corresponding author:

Email : jira@umc.ac.id

DOI : https://doi.org/10.31004/edukatif.v4i1.1804

ISSN 2656-8063 (Media Cetak)

ISSN 2656-8071 (Media Online)

Edukatif : Jurnal Ilmu Pendidikan Vol 4 No 1 Tahun 2022

p-ISSN 2656-8063 e-ISSN 2656-8071 
202 Penggunaan Media Quiziz Sebagai Sarana Pengembangan Berpikir Kritis Siswa - Jira Rastal Arif, Aiman Faiz, Lidiya Septiani

DOI: https://doi.org/10.31004/edukatif.v4i1.1804

\section{PENDAHULUAN}

Sebagaimana yang kita ketahui, saat ini kita memasuki abad ke-21 yang dikenal dengan abad ilmu pengetahuan dan teknologi (Trilling dan Hood dalam Rusman, 2012: 20). Perkembangan teknologi dan ilmu pengetahuan berpengaruh dalam proses pembelajaran abad ke-21, dalam proses pembelajaran abad 21 ini adanya pemanfaatan teknologi dan informasi yakni menggunakan komputer serta internet untuk proses pembelajaran dalam kelas. Keberadaan teknologi pada saat pembelajaran harus dianggap terbiasa, bahkan dimasa yang akan datang komputer dianggap sama keberadaannya dengan media alat tulis ataupun media yang tidak tergolong dalam teknologi di setiap ruangan kelas.

Perhatian utama pendidikan di abad 21 adalah untuk mempersiapkan hidup dan kerja bagi masyarakat (Trilling dan Hood dalam Rusman, 2012: 20). Abad 21 ini merupakan abad pengetahuan dengan tuntutan yang lebih mendalam serta rumit. Dampak abad ini yaitu perubahan cara pandang manusia kepada manusia lainnya, cara dan sudut pandang terhadap pendidikan, perubahan peran orang tua, guru, serta perubahan pola hubungan antara pihak terlibat. Hal tersebut artinya bahwa aspek pendidikan harus mampu mengikuti kondisi yang ada (Faiz et al., 2021).

Salah satu indikator bahwa perubahan sudah mulai terjadi dalam dunia pendidikan adalah terkait kebijakan pemerintah Indonesia sebagai upaya memutus mata rantai penyebaran Covid-19 mewajibkan pembelajaran menggunakan media teknologi (Faiz, 2021). Sekolah yang semula dilaksanakan secara tatap muka menjadi dilakukan secara daring (Wiresti, R. D., \& Munastiwi, 2021). Pemerintah menetapkan kebijakan ini sebagai upaya untuk menekan nyebaran virus Covid-19. Sekolah disinnyalir menjadi salah satu media yang menjadi potensi menyebarkan virus Covid-19, dikarenakan interaksi secara langsung antara siswa, guru, dan orang tua (Chusna, P. A., \& Utami, 2020). Penerapan belajar dari rumah yang berkepanjangan ini menjadikan guru maupun orang tua mengalami banyak kesulitan dan kendala karena tidak mempunyai persiapan sehingga hal tersebut memunculkan kejenuhan belajar dalam diri siswa (Hanina et al., 2021; Yuhenita, N. N., \& Indiati, 2021). Artinya bahwa perlu disosialisasikan kembali dan beradaptasi terkait penggunaan media teknologi dalam pembelajaran.

Perkembangan teknologi di dunia pendidikan saat ini salah satunya adanya inovasi media pembelajaran berbasis website yang efektif serta menyenangkan bagi anak. Beberapa jenis media pembelajaran online berbasis web yaitu E-Learning, Quizizz, Teka-teki silang, Google Classroom, E-book, Edmodo dan lain-lain. Kelebihan media pembelajaran online berbasis web ini yaitu:

1. Memungkinkan setiap pengguna dimanapun, kapanpun, untuk mempelajari apapun,

2. Pengguna dapat belajar dengan karakteristik dan langkah dirinya sendiri, karena pembelajaran berbasis web membuat pembelajaran bersifat individual serta kemandirian,

3. Kemampuan untuk membuat tautan (link), sehingga pengguna dapat mendapatkan informasi dari berbagai sumber, baik di dalam maupun di luar lingkungan belajar,

4. Sangat berpotensial sebagai sumber belajar bagi pengguna yang tidak memiliki cukup waktu untuk belajar,

5. Mendorong pengguna untuk lebih aktif dan mandiri dalam pembelajaran,

6. Menyediakan sumber belajar tambahan yang digunakan untuk memperkaya serta menambah materi pembelajaran,

7. Menyediakan mesin pencari yang digunakan untuk informasi serta sumber yang mereka butuhkan,

8. Isi dari materi pembelajaran dapat diperbaharui dengan mudah.

Sebagai media pembelajaran yang diharapkan akan menjadi bagian dari suatu proses belajar di sekolah, internet diharapkan mampu memberikan dukungan bagi terselenggaranya proses komunikasi interaktif antara guru dan siswa. Situasi ini perlu didukung oleh internet berkaitan dengan strategi pembelajaran yang dikembangkan, ialah sebagai kegiatan komunikasi yang dilaksanakan untuk mendorong siswa agar 
203 Penggunaan Media Quiziz Sebagai Sarana Pengembangan Berpikir Kritis Siswa - Jira Rastal Arif, Aiman Faiz, Lidiya Septiani

DOI: https://doi.org/10.31004/edukatif.v4i1.1804

mengerjakan tugas-tugas dan membantu siswa dalam memperoleh ilmu pengetahuan yang dibutuhkan dalam mengerjakan tugas sekolah (Daryanto, 2018).

Berpikir kritis (critical thinking) merupakan klasifikasi dari Higher-Other Thinking Skill (HOTS) bukan sekedar menghapalkan fakta maupun konsep, namun lebih kepada mengharuskan peserta didik untuk melakukan sesuatu terhadap fakta-fakta maupun konsep tersebut (Nurjaman, 2020). Dalam hal ini, peserta didik harus mampu bertindak untuk memahami, memaknai serta mengimplementasikan suatu pemikiran yang harus dituangkan dalam suatu permasalahan didalam pembelajaran saat berlangsung. Demikian, dapat disimpulkan kemampuan berpikir kritis adalah suatu tindakan berpikir secara sadar dengan cara mencermati memahami serta menganalisis dengan teliti dalam suatu konsep permasalahan didalam pembelajaran.

Jika siswa tidak dikembangkan dengan keterampilan berpikir kritis, maka siswa tidak mampu untuk menyerap materi yang lebih mendalam. Tetapi, dalam hal ini pada fakta dilapangan beberapa guru tidak menanamkan metode pembelajaran yang menarik untuk membentuk peserta didik dengan kemampuan berpikir kritis. Apalagi disaat pandemi Covid-19 seperti ini, anak-anak wajib belajar dari rumah. Kurang menariknya kegiatan pembelajaran online membuat siswa mudah jenuh dan cenderung pasif saat pembelajaran menggunakan media zoom meeting karena guru hanya menjelaskan materi saja, peserta didik hanya menyimak guru saat menjelaskan di media zoom meeting tersebut. Untuk itu penelitian ini untuk mengungkapkan efektifitas penggunaan media teknologi sebagai stimulus untuk merangsang pemikiran kritis para siswa dengan bantuan media quizizz.

\section{METODE PENELITIAN}

Peneliti ini menggunakan penelitian kualitatif, penelitian kualitatif bersifat naturalistik dan bersifat alamiah. Penelitian kualitatif juga merupaka pendekatan yang menekankan pada pemaknaan dan konteks pendeskripsian lebih bersifat rich and thick description (Creswell, 2010; Kurniawaty et al., 2021). Metode penelitian kualitatif sering disebut metode penelitian naturalistik karena penelitiannya dilakukan pada kondisi yang alamiah (natural setting), disebut juga sebagai metode etnographi, karena pada awalnya metode ini lebih banyak digunakan untuk penelitian bidang antropologi budaya, disebut sebagai metode kualitatif, karena data yang terkumpul dan analisisnya lebih bersifat kualitatif (Sugiyono, 2012: 13). Objek dalam penelitian ini yaitu penggunaan media website permainan edukasi dalam pembelajaran online terhadap berpikir kritis siswa. Adapun responden dalam penelitian ini adalah siswa Kelas V yang berada di SD Negeri Kartini Kota Cirebon, Jawa Barat. Adapun untuk mendapatkan hasil penelitian ini dilakukan selama 2 bulan. Teknik pengumpulan data penelitian ini, yaitu observasi dan wawancara kepada siswa kelas V.

Analisis data terhadap jawaban siswa berlangsung pada saat pengumpulan dan setelahnya. Karena beberapa hasil analisis belum memuaskan, peneliti melakukan wawancara kembali untuk memperoleh kredibilitas (Miles \& Hubberman, 1992). Analisa data dilakukan secara interaktif dan berkelanjutan sampai data tersebut tuntas dan jenuh, atau jawaban serupa. Hal ini didapatkan melalui proses reduction (reduksi data), data display (penyajian data), dan data conclusion drawing/ verification (penarikan kesimpulan) (Sugiyono, 2013: 337; Faiz \& Soleh, 2021). 
204 Penggunaan Media Quiziz Sebagai Sarana Pengembangan Berpikir Kritis Siswa - Jira Rastal Arif, Aiman Faiz, Lidiya Septiani

DOI: https://doi.org/10.31004/edukatif.v4i1.1804

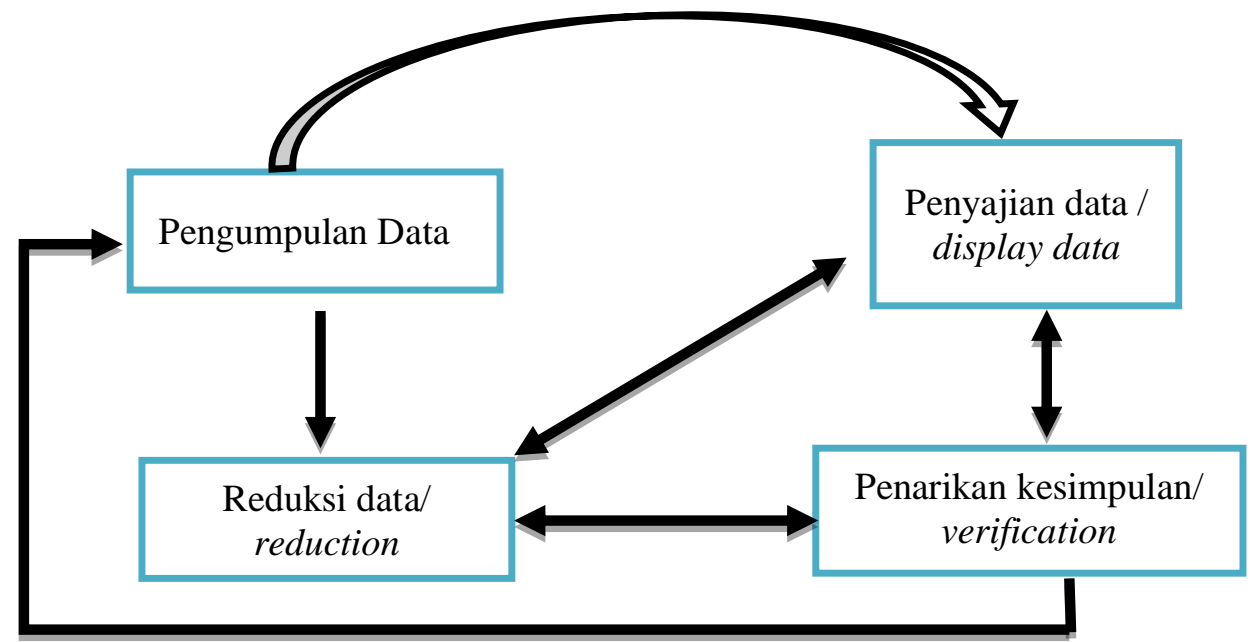

Gambar 1. alur analisis data

\section{HASIL DAN PEMBAHASAN PENELITIAN}

Berdasarkan observasi dilapangan bahwa penggunaan media quizizz dan teka-teki silang berbasis website, dapat di evaluasi siswa dapat membentuk daya berpikir kritis saat menjawab kuis-kuis dalam implementasi media quizizz dan teka-teki silang. Hal ini dibuktikan dengan pengamatan atau observasi via zoom saat pengerjaan sedang dimulai. Tidak hanya itu observasi juga melihat hasil akhir pengerjaan dalam siswa menjawab kuis-kuis quizizz dan teka-teki silang. Tidak hanya itu guru sebelum menyelesaikan pembelajaran online menanyakan materi secara acak yang telah dijelaskan pada saat pembelajaran. Maka dari itu evaluasi pembelajaran online dengan media quizizz dan teka-teki silang harus dipantau oleh guru agar mengetahui daya pembentukkan daya pikir kritis siswa saat mengerjakan.

Hasil wawancara dengan Pak OP bahwa adanya tujuan dalam penggunaan media quizizz dan teka-teki silang ini untuk mengingatkan kembali materi yang telah guru jelaskan. Pada saat siswa mengerjakan quizizz dan teka-teki silangnya dapat melaksanakan dengan baik, nilainya bagus, dan dapat membentuk daya ingat siswa memahami penjelasan materi yang telah guru jelaskan. Maka dari itu dengan aksen-aksen, gambargambar yang menarik serta waktu yang di tentukan dengan satu soal 20 detik ini dapat menstimulasi siswa menjawab pertanyaan dalam media quizizz ini dengan tepat. Sedangkan dengan media teka-teki silang siswa menjawab teka-teki pertanyaan dengan waktu 10 menit. 
Penggunaan Media Quiziz Sebagai Sarana Pengembangan Berpikir Kritis Siswa - Jira Rastal Arif, Aiman Faiz, Lidiya Septiani

DOI: https://doi.org/10.31004/edukatif.v4i1.1804

\begin{tabular}{|c|c|c|c|}
\hline \multirow[b]{2}{*}{ Questions } & \multicolumn{3}{|c|}{ Class Level } \\
\hline & \# Correct & \# Incorrect & \# Unattempted \\
\hline Contoh sumber energi panas adalah, kecuali... & 27 & 5 & 0 \\
\hline $\begin{array}{l}\text { Benda yang dapat menghantarkan panas dengan baik } \\
\text { dinamakan... }\end{array}$ & 28 & 4 & 0 \\
\hline $\begin{array}{l}\text { Alat yang digunakan untuk mengumpulkan energi panas } \\
\text { matahari disebut... }\end{array}$ & 26 & 6 & 0 \\
\hline $\begin{array}{l}\text { Benda-benda yang tidak bisa menghantarkan panas dengan baik } \\
\text { atau dengan cepat, yaitu... }\end{array}$ & 26 & 6 & 0 \\
\hline $\begin{array}{l}\text { Nelayan pergi ke laut pada malam hari antara lain karena pada } \\
\text { malam hari terjadi... }\end{array}$ & 16 & 16 & 0 \\
\hline Total & 123 & 37 & 0 \\
\hline
\end{tabular}

\section{Gambar 2. Hasil Penggunaan Quizizz terhadap Berpikir Kritis Siswa}

Sumber: Dokumentasi Peneliti.

Pada saat siswa mengerjakan teka-teki silang ini siswa mengerjakan dengan penuh teliti dikarenakan siswa harus mencocokan rumpang kotak yang kosong dengan jawaban yang tepat. Siswa dalam mengerjakan teka-teki silang diberikan waktu manual oleh gurunya yaitu 10 menit. Hasil dalam pengerjaan soal kuis tekateki silang ini bahwa 32 siswa pada saat itu mengerjakan nomer soal dengan tepat semua. Jika siswa mengerjakan dengan tepat maka rumpang kotak tersebut berwarna hijau untuk tulisan di rumpang kotaknya serta bertanda ceklis di setiap soal. Hal ini bahwa dalam pengerjaan teka-teki silang yaitu perlu adanya kreatifitas dalam mengerjakannya serta berpikir kritis untuk menjawab pertanyaan dengan tepat serta cocok dengan kotaknya. Dilihat dari segi soal, adanya kesukarannya pada soal pertanyaan teka-teki silang, namun soal mengacak dikarenakan teka-teki silang sistemnya menurun dan mendatar. Saat pengerjaan teka-teki silang dengan waktu yang lumayan lama sehingga anak dapat diberi kesempatan mengerjakan soal kuis dengan penuh ketelitian serta tidak menimbulkan kepanikan pada saat mengerjakan.

Pada saat evaluasi quizizz ada kelebihan yaitu siswa tidak dapat bertanya atau mencontek kepada temannya, kemudian karena adanya waktu yang telah ditentukan dalam satu soalnya, siswa dalam menjawab quizizz tidak punya kesempatan untuk bertanya dengan orang sekitar atau melihat buku catatan maupun mencari jawaban di platform google. Maka dari itu dengan adanya Saat setelah mengerjakan quizizz, siswa dapat mengetahui peringkat dari keseluruhan siswa yang telah mengerjakan quizizz tersebut. Siswa saat menjawab soal-soal didalam media quizizz dapat mengetahui jawaban yang benar dan salah dari soalnya yang telah dikerjakan. Sedangkan media teka-teki silang kelebihannya yaitu siswa dapat mengerjakan secara individual tanpa harus bersamaan dengan siswa yang lainnya, tidak adanya waktu dalam soalnya, serta siswa dapat membentuk daya pikir kritis serta kreatifitas dikarenakan teka-teki silang ini harus mencocokan jumlah kotak yang tersedia dengan jawaban yang dianggap cocok terhadap bagian kotaknya.

Dalam pembahasan evaluasi penggunaan quizizz dan teka-teki silang terhadap berpikir kritis siswa bahwa siswa mengalami kesulitan saat menjawab soal dalam media quizizz dikarenakan waktu terlalu cepat. Tetapi, dengan adanya waktu yang terlalu cepat ini dapat melatih kemampuan daya pikir berpikir kritis siswanya agar mampu lebih memacu daya ingat materi yang telah dijelaskan oleh guru. Sedangkan teka-teki silang siswa tidak mengalami kesulitan dikarenakan waktu tidak cepat seperti media quizizz. Teka-teki silang 
206 Penggunaan Media Quiziz Sebagai Sarana Pengembangan Berpikir Kritis Siswa - Jira Rastal Arif, Aiman Faiz, Lidiya Septiani

DOI: https://doi.org/10.31004/edukatif.v4i1.1804

dalam hal ini dapat melatih kreativitas dan membentuk daya pikir siswa terhadap jumlah rumpang kotak yang kosong, sehingga jawaban harus cocok dengan rumpang kotak yang kosong.

Proses pembelajaran online harus bersifat menyenangkan, pada dasarnya siswa jika pembelajaran online menyenangkan maka motivasi untuk keingintahuannya lebih tinggi. Oleh karena itu, ada media yang dapat menyenangkan serta membuat keigintahuan siswa lebih tinggi termasuk penggunaan media quizizz dan tekateki silang. Purba dalam (Mulatsih, 2020) mengatakan bahwa quizizz memiliki karakteristik permainan seperti adanya tema background, musik, serta aksesories lain yang dapat membuat efek menyenangkan selama kegiatan proses pembelajaran online. Quizizz dapat membuat siswa bersaing dengan mendapatkan poin tertinggi dan memotivasi pembelajaran online sehinggan dalam perkembangan proses belajar meningkat. Quizizz dapat dimainkan pada saat bersamaan serta jika telah dikerjakan dapat keluar langsung papan peringkat anggota yang bermain dalam media permainan kuis berbasis web. Adapun untuk teka-teki silang dapat membentuk perkembangan siswa pada saat pembelajaran online melalui media yang menyenangkan Hidayat (dalam Sababalat, D. F., Purba, L. S. L., \& Sormin, 2021) mengatakan bahwa menyatakan pengimplementasian media teka-teki silang dapat membuat rasa jenuh berkurang terhadap siswa ketika kegiatan proses pembelajaran berlangsung.

Siswa dalam mengerjakan soal pertanyaan dalam bentuk quizizz dan teka-teki silang untuk melihat atau mengamati pembentukkan daya ingat serta daya berpikir kritis siswa. Bahwasanya Lismaya (2019: 5) mengatakan berpikir kritis adalah sebuah proses kecerdasan, serta adanya menciptakan konsep, serta penerapan dengan menilai semua informasi yang diperoleh dari sebuah penjelasan serta pengamatan, pengalaman dilapangan, pemikiran mendalam atau komunikasi sebagai dasar untuk dapat mempercayakan dan membuat suatu adanya tindakan. Oleh sebab itu dalam pembelajaran online dengan mengggunakan media quizizz dan teka-teki silang siswa dapat mengimplementasikan daya ingat materi yang telah dijelaskan guru, dengan mengamati adanya peristiwa dalam kehidupan sehari-hari. Siswa mencoba menggunakan dengan suatu media pembelajaran yang dapat membuat suasana belajar lebih hidup serta lebih menyenangkan, aktif, dan kritis terhadap pertanyaan yang telah direncanakan guru didalam kuis berbasis web tersebut.

Sebagaimana hasil penelitian, tujuan awal berpikir kritis adalah menyingkapkan kebenaran dengan menyerang dan menyingkirkan semua yang salah supaya kebenaran akan terlihat. Hal ini penting untuk mencegah penggunaan bahasa, konsep, dan augmentasi salah yang sembarangan. Akan tetapi, berpikir kritis semata-mata tidak memiliki kekuatan yang generatif maupun konstruktif. Berpikir kritis adalah proses intelektual, menciptakan konsep, penerapan, membuat sintesis dan menilai semua informasi yang diperoleh dari observasi, pengalaman dilapangan, refleksi, pemikiran mendalam atau komunikasi sebagai dasar untuk dapat mempercayakan dan membuat tindakan (Lismaya, 2019: 8).

Berpikir kritis sebagai cognitive skill, didalamnya terdapat kegiatan interpretasi, analisis, evaluasi, inferensi, penjelasan, serta pengelolaan diri.

1. Interpretasi adalah kemampuan untuk memahami clan menjelaskan pengertian dari situasi, pengalaman, kejadian, data, keputusan, konvensi, kepercayaan, aturan, prosedur dan kriteria.

2. Analisis adalah mengidentifikasi hubungan dari beberapa pernyataan pertanyaan, konsep, deskripsi, dan berbagai model yang dipergunakan untuk merefleksikan pemikiran, pandangan, kepercayaan, keputusan, alasan, informasi dan bukni. Mengevaluasi ide dan pendapat orang lain, mendeteksi argumen dan menganalisis argumen merupakan bagian dari analisis.

3. Evaluasi adalah kemampuan untuk menguji kebenaran pernyataan yang digunakan untuk menyampaikan pemikiran. persepsi, pandangan, keputusan, alasan, sena opini. Evaluasi juga merupakan kemampuan untuk menguji hubungan berbagai pernyataan, deskripsi, pertanyaan, dan bentuk lain yang dipa-kai dalam merefleksikan pemikiran.

4. Inferensi adalah kemampuan untuk mengidentifikasi dan memilih demen yang dibutuhkan untuk menyusun simpulan yang memiliki alasan. untuk menduka dan menegakkan diagnosis. Untuk 
207 Penggunaan Media Quiziz Sebagai Sarana Pengembangan Berpikir Kritis Siswa - Jira Rastal Arif, Aiman Faiz, Lidiya Septiani

DOI: https://doi.org/10.31004/edukatif.v4i1.1804

mempertimbangkan informasi apa sajakah yang dibutuhkan dan untuk memutuskan konsekuensi yang hams diambil dari data, informasi, pernyataan, kejadian, prinsip, konsep dan lain sebagainya.

5. Kemampuan menjelaskan adalah kemampuan menyatakan hasil pemikiran, penjelaskan alasan berdasarkan pertimbangan bukti, konsep metodologi, kriteriologi dan konteks. Termasuk dalam ketrarnpilan ini adalah kemampuan menyampaikan hasil, menjelaskan prosedur, dan mempresentasikan argumen.

6. Self regulation adalah kemampuan seseorang untuk mengatur sendiri dalam berpikir. Dengan kemampuan ini seseorang akan selalu memeriksa ulang hasil berpikirnya untuk kemudian diperbaiki sehingga menghasilkan keputusan yang lebih baik. Berpikir kritis sebenarnya merupakan proses melibatkan integrasi pengalaman pribadi, pelatihan, dan skill (kemampuan/kemahiran) disertai dengan alasan dalam mengambil keputusan untuk menjelaskan kebenaran sebuah informasi. Atau dengan kata lain merupakan aktivitas mengidentifikasi suatu permasalahan dengan menggunakan pengalaman sebelumnya dan mencari hubunganan antara permasalah tersebut dan memecahkannya pada situasi yang berbeda (Lismaya, 2019: 9).

Sedangkan domain kognitif adalah domain "berpikir". Domain ini berfokus pada keterampilan intelektual dan akrab bagi pendidik. Taksonomi Bloom revisi (mengingat, pemahaman, aplikasi, analisis, evaluasi, dan membuat) sering digunakan untuk menggambarkan peningkatan kompleksitas keterampilan kognitif saat siswa bergerak maju dari tingkat pemula ke tingkat yang lebih tinggi dalam pengetahuan mereka.

Kemampuan berpikir/intelektual para siswa akan berkembang dimulai dari tingkat $\mathrm{C} 1$ yakni mengingat (remember) pada tahap ini siswa akan mengingat kembali pengetahuan yang sudah pernah dipelajari sebelumnya dari memorinya. Tahapan perkembangan selanjutnya C2 yakni pemahaman (understand), merupakan kemampuan para siswa untuk membangun dan menggabungkan makna dari pesan pembelajaran, baik sccara lisan, tulisan maupun gambar, menerjemahkan, menjelaskan fakta, konsep, prinsip, hukum, dan teori. Tingkatan selanjutnya adalah C3 yakni menerapkan (apply): merupakan penggunaan fakta, konsep, hukum, teori, prinsip, pengetahuan, dan keterampilan untuk memecahkan masalah terkait. Tahap lebih lanjut C4 yakni menganalisis (analyse); membandingkan, menguraikan persamaan, perbedaan dan hubungan anatara satu dengan yang lain. Tingkatan taksonomi pengetahuan selanjutnya C5 yakni mengevaluasi (evaluate): membuktikan, verifikasi, kritik, menarik kesimpulan, memberikan pendapat atas pernyataan, penemuan, prinsip, teori. Dapat juga dikatakan evaluasi merupakan kemampuan membuat keputusan berdasarkan kriteria dan standar. Kemampuan tertinggi adalah C6 yakni mengkreasi (create), merupakan kemampuan menempatkan elemen-elemen sccara bersamaan ke dalam bentuk modifikasi atau mengorganisasikan elemenelemen ke dalam pola baru (struktur baru) (Ambiyar dan Panyahuti, 2020: 28).

Bahwa berdasarkan pendapat ahli diatas bahwa berpikir kritis adalah sebuah proses daya pikir seseorang bila diberikan masalah atau materi dilapangan maka akan terus memaknai serta mengimplementasikan suatu pemikiran yang harus dituangkan dalam suatu permasalahan didalam pembelajaran saat berlangsung.

Dalam berikir kritis ada enam unsur dasar dalam berpikir kritis yang dikenal dengan singkatan FRISCO (Focus, Reason, Inference, Situation, Clurity, Overview). Adapun penjelasan dari FRISCO adalah sebagai berikut (Amelia, K., \& Astuti, 2020):

1. Focus (fokus), artinya memusatkan perhatian terhadap pengambilan keputusan dari permasalahan yang ada.

2. Reason (alasan), memberikan alasan rasional terhadap keputusan yang diambil.

3. Inference (simpulan), membuat simpulan yang berdasarkan bukti yang meyakinkan dengan cara mengidentifikasi berbagai argumen atau anggapan dan mencari alternatif pemecahan, serta tetap mempertimbangan situasi dan bukti yang ada.

4. Situation (situasi), memahami kunci dari permasalahan yang menyebabkan suatu keadaan atau situasi.

5. Clarity (kejelasan), memberikan penjelasan tentang makna dari istilah-istilah yang digunakan. 
208 Penggunaan Media Quiziz Sebagai Sarana Pengembangan Berpikir Kritis Siswa - Jira Rastal Arif, Aiman Faiz, Lidiya Septiani

DOI: https://doi.org/10.31004/edukatif.v4i1.1804

6. Overview (memeriksa kembali), melakukan pemeriksaan ulang secara menyeluruh untuk mengetahui ketepatan keputusan yang sudah diambil.

Adapun tahapan Berpikir Kritis menurut Norris dan Ennis mengungkapkan satu set tahapan yang termasuk proses berpikir kritis diantaranya; 1) Mengklafikasi isu dengan mengajukan pertanyaan kritis; 2) Mengumpulkan informasi tentang isu; 3) Mulai bernalar melalui sudut pandang; 4) Mengumpulkan informasi dan melakukan analisis lebih lanjut, jika diperlukan; 5) Membuat dan mengkomunikasikan keputusan (Norris dan Ennis dalam Lismaya, 2019: 10).

Berpikir kritis merupakan berpikir masuk akal dan reflektif yang difokuskan pada pengambilan keputusan tentang apa yang dilakukan atau diyakini. Masuk akal berarti berpikir didasarkan atas fakta-fakta untuk menghasilkan keputusan yang terbaik, reflektif arinya mencari dengan sadar dan tegas kemungkinan solusi yang terbaik. Dengan demikian berpikir kritis, menurut Norris dan Ennis adalah berpikir yang terarah pada tujuan. Tujuan dari berpikir kritis adalah mengevaluasi tindakan atau keyakinan yang terbaik (Norris dan Ennis dalam Lismaya, 2019: 10). Norris dan Ennis bahwa memfokuskan kerangkanya pada proses berpikir yang melibatkan pengumpulan informasi dan penerapan kriteria untuk mempertimbangkan serangkaian tindakan atau pandangan yang berbeda (Norris dan Ennis dalam Lismaya, 2019: 10).

Dalam berpikir kritis terdapat beberapa indikator berpikir kritis yang berkaitan dengan mata pelajaran, yaitu:

1. Memberikan penjelasan sederhana, yang meliputi:
a. Memfokuskan pertanyaan;
b. Menganalisis pertanyaan;
c. Bertanya dan menjawab tentang suatu penjelasan atau tantangan.

2. Membangun keterampilan dasar, yang meliputi:

a. Mempertimbangkan sumber yang dapat dipercaya;

b. Mengamati dan mempertimbangkan suatu laporan hasil observasi.

3. Menyimpulkan, yang meliputi:

a. Membuat deduksi dan mempertimbangkan hasil deduksi;

b. Membuat induksi dan mempertimbangkan hasil induksi; dan

c. Membuat dan menentukan nilai pertimbangan.

4. Memberikan penjelasan lanjut, yang meliputi:

a. Mendefinisikan istilah dan pertimbangan definisi;

b. Mengidentifikasi asumsi.

5. Mengatur strategi dan taktik, yang meliputi:

a. Menentukan tindakan;

b. Berinteraksi dengan orang lain (Kumalasari, R., \& Susanto, 2017)

Dengan demikian penggunaan media quizizz dalam pembelajaran online secara garis dominan mampu merangsang siswa untuk berpikir secara kritis dan mampu memecahkan soal-soal yang menjadi indikator dalam berpikir kritis.

\section{KESIMPULAN}

Penggunaan media website permainan edukasi dalam pembelajaran online dengan media quizizz dan teka-teki silang dapat membentuk adanya berpikir kritis terhadap siswa dalam pembelajaran online dan mampu menangkap daya ingat siswa. Adanya stimulus mampu memberi rangsangan agar siswa mau lebih kritis dan mencari tau lebih jauh, hal ini tentu akan berpengaruh pada proses kecerdasan, serta adanya menciptakan konsep, serta penerapan dengan menilai semua informasi yang diperoleh dari sebuah penjelasan serta pengamatan, pengalaman dilapangan, pemikiran mendalam atau komunikasi sebagai dasar untuk dapat mempercayakan dan membuat suatu tindakan. 
209 Penggunaan Media Quiziz Sebagai Sarana Pengembangan Berpikir Kritis Siswa - Jira Rastal Arif, Aiman Faiz, Lidiya Septiani

DOI: https://doi.org/10.31004/edukatif.v4i1.1804

\section{DAFTAR PUSTAKA}

Ambiyar dan Panyahuti. (2020). Asesmen Pembelajaran Berbasis Komputer dan Android . Kencana.

Amelia, K., \& Astuti, S. (2020). Efektivitas Penerapan Model Discovery Learning dan Inquiry Terhadap Keterampilan Berpikir Kritis Pembelajaran Subtema Perubahan Bentuk Energi Kelas III Gugus Sudirman. Jurnal Ilmiah Wahana Pendidikan, 6(2), 151-157.

Chusna, P. A., \& Utami, A. D. M. (2020). Dampak pandemi COVID-19 terhadap peran orang tua dan guru dalam meningkatkan kualitas pembelajaran daring anak usia sekolah dasar. Premiere: Journal of Islamic Elementary Education, 2(1), 11-30.

Creswell, J. W. (2010). Research Design Qualitative Approach. London Publication. Lesson In Personal Change. A Fireside Book.

Daryanto, J. (2018). Penggunaan Media Pembelajaran Video Interaktif untuk Meningkatkan Pemahaman Tembang Macapat Dalam Pembelajaran Bahasa Daerah pada Siswa Sekolah Dasar. Jurnal Pendidikan Dasar, 6(1).

Faiz, A. (2021). Peran Filsafat Progresivisme dalam Mengembangkan Kemampuan Calon Pendidik di Abad21. Jurnal Education and Development Institut Pendidikan Tapanuli Selatan, 9(1), 131-135.

Faiz, A., Hakam, K. A., Nurihsan, J., \& Komalasari, K. (2021). Development of Moral Dilemma Model in Elementary School. 1st International Conference In Education, Science And Technology, 17-22.

Faiz, A., \& Soleh, B. (2021). Implementasi pendidikan karakter berbasis kearifan lokal. JINoP (Jurnal Inovasi Pembelajaran), 7(1), 68-77. https://doi.org/10.22219/jinop.v7i1.14250

Hanina, P., Faiz, A., \& Yuningsih, D. (2021). Upaya Guru dalam Mengatasi Kejenuhan Belajar Peserta Didik di Masa Pandemi. Basicedu, 5(5), 3791-3798. https://doi.org/10.31004/basicedu.v5i5.1402

Kumalasari, R., \& Susanto, B. (2017). Pengaruh layanan informasi bimbingan konseling berbantuan media audio visual terhadap empati siswa. Counsellia: Jurnal Bimbingan Dan Konseling, 7(1), 20-27.

Kurniawaty, I., Dahliyana, A., \& Faiz, A. (2021). Edukatif: Jurnal Ilmu Pendidikan Kearifan Lokal Sunda dalam Kegiatan Rebo Nyunda dan Potensinya untuk Tujuan Wisata Pendidikan. 3(6), 5035-5042.

Lismaya, L. (2019). Berpikir Kritis \& PBL: (Problem Based Learning) - - Google Buku. Media Sahabat Cendekia.

Miles \& Hubberman. (1992). Analisis data kualitatif: Buku sumber tentang metode-metode baru (Tjetjep Rohendi Rohidi (ed.)). UI Press.

Mulatsih, B. (2020). Penerapan aplikasi Google Classroom, Google Form, dan Quizizz dalam pembelajaran kimia di masa pandemi Covid-19. Ideguru: Jurnal Karya Ilmiah Guru, 5(1), 16-26.

Nurjaman, A. (2020). Peningkatan Kemampuan Berpikir Kritis Dalam Pembelajaran Pendidikan Agama. Cv. Adanu Abimata.

Rusman. (2012). Belajar dan Pembelajaran berbasis Komputer: Mengembangkan Profesionalisme Guru Abad 21. Alfabeta.

Sababalat, D. F., Purba, L. S. L., \& Sormin, S. (2021). Efektivitas pemanfaatan media pembelajaran teka-teki silang online terhadap peningkatan minat belajar siswa. EduMatSains: Jurnal Pendidikan, Matematika Dan Sains, 6(1), 207-218.

Sugiyono. (2012). Metode Penelitian Bisnis. Alfabeta.

Sugiyono. (2013). Metode Penelitian Kuantitatif, Kualitatif dan R \& D.Bandung:Alfabeta. Metode Penelitian Kuantitatif, Kualitatif Dan R \& D.Bandung:Alfabeta., April 2015, 31-46. https://doi.org/10.1017/CBO9781107415324.004

Wiresti, R. D., \& Munastiwi, E. (2021). Deskripsi Rekonstruksi Pembelajaran Anak Usia Dini Study From Home pada Masa Pandemik Covid-19. Jurnal Ilmiah Visi, 16(1), 47-56. 
210 Penggunaan Media Quiziz Sebagai Sarana Pengembangan Berpikir Kritis Siswa - Jira Rastal Arif, Aiman Faiz, Lidiya Septiani

DOI: https://doi.org/10.31004/edukatif.v4i1.1804

Yuhenita, N. N., \& Indiati, I. (2021). Tingkat Resiliensi Orang Tua dalam Mendampingi Anak Sekolah dari Rumah pada Masa Pandemi. Jurnal Basicedu, 5(6), 5336-5341. 